\title{
A CAVE AS A THIRD SPACE IN TOM SCHULMAN'S PLAY DEAD POETS SOCIETY; PRACTICAL INSPIRATION FOR TEACHERS
}

\author{
Eka Sugeng Ariadi \\ Graduate Student of The State University of Surabaya \\ e-mail: sugengariadieka@gmail.com
}

\begin{abstract}
Abstrac
Literacy is not a matter of talking and discussing the improvement of reading and writing skills, yet more than that, it is extending as a kind of social practice which involving people's mundane life to generate specific and unique products of each person. Luckily, literacy can be a put in other subjects; literature and education. In this paper, the notion of third space in literacy is applied as the tool to analyze the role of a cave in Tom Schulman's play Dead Poets Society, which then influencing a group of Welton Academy students' awareness of their personal identities, their own cognition and their knowledge needed. To examine the students' movements in connecting three spaces; home, school, and cave, the researcher uses the Knowledge and Cognitive Process dimension, which is retrieved from Bloom's taxonomy revision as proposed by Krathwohl (2002). The result confirms that the role of a cave, as third space, assists much the students to seek their own voices and identities, and definitely rises their confidence, creativities, and innovations for better transformation.
\end{abstract}

Keywords: Third space, Literacy, Literature, Teaching

\section{INTRODUCTION}

At the beginning, literacy was simply determined as a set of reading and writing skills. Contemporary, it has been broadening not only as a set of skills but also as a social practice, which means engaging people's activities in the mundane, at work or at school to generate skills' productions. Then, it is popular as New Literacy Studies (Barton, Hamilton, \& Ivanič, 2000; Luke, 2005). In his writing, Allan Luke states New Literacy Studies was inspired by Paulo Freire's 'practice of freedom', and New London Group's 'critical and transformed practice' three decades ago and was dedicated as "a cultural and ultimately political response: an abiding commitment to literacy as a means of social transformation -for individuals and communities, for cultures and nationstates," (p. xiii). 
Today, this literacy has the amount of theoretical, practical and pedagogical research immersed in diverse fields; literature, education, linguistics, ethnography, and so forth. Several key concepts as the basic theory of this literacy are applied to strengthen the research or experiment. One of them is third space (Moje et al., 2004; Pahl \& Rowsell, 2005; Wilson, 2000). In this present study, this theory employs to reveal the values in correlation with educators or teachers' teaching and learning process which appear in Tom Schulman's play Dead Poets Society (Script, 2007). In a field of education, the researcher governs the Knowledge dimension and the Cognitive Process dimension as Bloom's Taxonomy revised which proposed by Krathwohl (2002). This play is recognized as one of the best drama and much inspiring for teachers in the wide world, nonetheless, less scholars analyze it through the eye of New Literacy Studies. Accordingly, the writer argues that third space (Moje et al., 2004; Pahl \& Rowsell, 2005; Wilson, 2000), divulges the ways Mr. Keating's teaching and inspiring his students about the role of a cave and the existence of the secret community, alongside with the activities.

\section{Third Space}

The idea of third space as promoted by Wilson (2000), then sustained by Moje's third space (Moje et al., 2004), and revisited by Pahl and Rowsell (2005). Pahl and Rowsell (2005) consider the third space as a meeting space between home space and school space, blend and mix space, in which lets teachers think how their students' meaning-making happen between school and home. They argue that this idea subconsciously determines "students' language needs based on what they know and what they have experienced," (p. 105). For example teacher in a classroom offers the third space by using the noticeboard where students' words or texts freely are written with their artifacts, such as: photographs, or posters which they bring from homes or communities. This activity means students' identities are respected and appreciated, and additionally builds a link to the students' Discourse, funds of knowledge, and cultural capital in order to rise and transform their identities. Therefore, "writing and literacy are social and cultural processes that relate to our cultural identity," (Pahl \& Rowsell, 2005, p. 101). Again, in this present paper, the researcher examines the presence of a cave as a third space which appeared in Tom Schulman's play Dead Poets Society.

\section{The Knowledge and Cognitive Process Dimension}

The Knowledge and Cognitive Process dimension here are referred to the notion of revising Bloom's taxonomy proposed by Krathwohl (2002). There are some revisions stated in his paper, the first is "From One Dimension to Two Dimensions". It means from Knowledge dimension splits into two; Knowledge dimension and Cognitive Process dimension. The second is the detail in categories and subcategories from the prior revision. Basically, Knowledge dimension is emphasizing the noun aspects in the learning objectives, while Cognitive Process dimension is focusing on the verb aspects. 
In this present paper, Metacognitive Knowledge category in Knowledge dimensions and Remember category in Cognitive Process dimension is the midpoint of the discussion. Metacognitive Knowledge is the newest Knowledge category in this dimension, Krathwohl (2002) says it "involves knowledge about cognition in general as well as awareness of and knowledge about one's own cognition." While Remember category encompasses two sub categories; 1.1 Recognizing and 1.2 Recalling. Remember is described as "retrieving relevant knowledge from long-term memory."

Accordingly, this paper singles out the relationship and interconnection among three subjects; literacy, literature, and education. The concept of third space in literacy subject practices as a tool to observe the intended place, a cave, which appear in Tom Schulman's play Dead Poets Society. Eventually, the roles and the worthy things of a cave for teachers and students are then explored by means of education concepts in Bloom's taxonomy revised by Krathwohl (2002).

\section{RESULT AND DISCUSSION}

Third space should be initiated by teachers in order to encourage their students' preferences in learning, as it has been experienced by Mr. Keating toward his lovely classroom. By proposing this space, it supports students' meaning-making happened between school and home, and subconsciously determine "students' language needs to be based on what they know and what they have experienced," (p. 105). The space in this play is a cave. What is it? and how is it functioned fruitfully? Let see the script below.

\section{EXT. THE CAMPUS - LATER}

Keating walks across the school lawn wearing his sports coat and a scarf, carrying his books. Pitts, Neil, Cameron, Knox, Charlie, Meeks and Todd approach him.

NEIL

Mr. Keating? Sir? Oh Captain My Captain. (Keating stops) What was the Dead Poets Society?

KEATING

Ah, so you boy's have been snooping.

NEIL

I was just looking in an old annual and...

KEATING

Nothing wrong with research. (The boys wait for more.)

NEIL

But what was it? (Keating checks around to be sure they are unwatched.)

KEATING 
The Dead Poets was a secret organization. I don't know how the present administration would look upon it but I doubt the reaction would be favorable. Can you keep a secret? (An instant sea of nods.)

KEATING

The Dead Poets Society was dedicating to sucking the marrow out of life. That phrase is by Thoreau and was invoked at every meeting. A small group of us would meet at a cave and there we would take turns reading Shelley,

Thoreau, Whitman, our own verse --any number of poets -- and, in the enchantment of the moment, let them work their magic on us.

KNOX

You mean it was a bunch of guys sitting around reading poetry?

KEATING

(amused) Both sexes participated, Mr. Overstreet. And, believe me, we did not simply read, we let it drip from our tongues like honey. Women swooned, spirits soared... Gods were created, gentlemen. (The boys think a minute.)

NEIL

What did the name mean? Did you only read dead poets?

KEATING

All poetry was acceptable. The name simply referred to the fact, that to join the organization, you had to be dead.

SEVERAL

What?

KEATING

Full membership required a lifetime of apprenticeship. The living were simply pledges.

Alas, even I am still a lowly initiate. The boys don't quite know what to say.

KEATING

The last meeting must have been 25 years ago. Hasn't been another since. (Keating exits. The boys stand watching. Neil turns to them.)

(Script, 2007, pp. 32-34)

The above excerpt shows that two decades-a half years ago, Mr. Keating and his friends were the creators of Death Poets Society, a secret community or organization made by particular students who studied on this campus. They met in a cave, located a mile from the campus, not only to read poetries several well-known poets as well as their own creations but also to write and express their opinions about the poetries. It means consciously a cave become another place (third space) beside campus and home (first and second spaces) to expose their desires, expressions, and passions in learning something and in revealing their identities. Indeed, as a creative youth and talented students, Keating and friends at that time needed a freedom, free area, or borderless place to shape and to build their own characters and to bridge their own needs with school's requirements. 
In literature subject, a cave can be regarded as denotative meaning and connotative meaning. Denotatively, the play shows that the cave is a place inside a mountain or hiding behind some trees, unseen easily by many people. Connotatively, a cave might represent a symbol of third space; a particular place beyond school and home. Rednaningdyah (2015), once in her website, gives clear examples of third spaces which ever experienced by herself; "Rawon Paidi" in Indonesian context, "Perpustakaan Koper BMI-HK" in Hong Kong context, and "Starbucks" in the Australian context. Peoples' activities at those places vary, such as having discussions on many topics and issues (school programs, natural phenomena, social and political movements, national or international topics, etc), sharing ideas, borrowing and lending books or anything, selling and buying stuff, creating and promoting somethings, and many possible things could be done in it.

In education subject, the above dialogue between Neil and friends and Mr. Keating is included in the first category of the Cognitive Process dimension in Bloom's taxonomy revised by Krathwohl (2002). Mr. Keating's true story about his past memory (twenty-five years ago) to their students belongs to 1.0 Remember category (the subcategories are 1.1 Recognizing and 1.2 Recalling), as the description pronounces the activity in this category is in "retrieving relevant knowledge from long-term memory" (Krathwohl, 2002). Krathwohl retrieves his long-term memory and tells the truths about the secrets community, the meeting place (a cave), the participants and all the activities inside the cave. As a poetry teacher and since it is relevant to his student's subject, of course, by telling about the Dead Poet Society, he hardly intends to elicit and encourage his students' motivation, creation, and innovation in achieving the classroom objectives, not solely do the same activities as he did.

Afterward, the excerpt script below portraits the incredible activities done by Neil and friends in a cave as initiated by Mr. Keating. Bravely, they escape from school at night in order to seek the cave and subsequently held some meetings there with various activities.

\section{EXT. THE SCHOOL GROUNDS - NIGHT}

The stars are out and the wind is blowing. A SERIES of SHOTS show the boys crossing the campus. They reach a stone wall with an old iron gate that is chained shut. The boys squeeze through the gate and disappear into the woods beyond.

\section{EXT. THE WELTON WOODS AND STREAM - NIGHT}

The boys make their way through the eerie forest searching for the cave. They reach the bank of the stream and begin looking for an appropriate spot amongst the tree roots and erosion. Charlie suddenly looms out of the cave entrance.

\section{CHARLIE}

Yaa, I'm a dead poet!

MEEKS 
(frightened) Ahh! (then recovering) Eat it, Dalton!

CHARLIE

This is it.

\section{INT. THE CAVE - A BIT LATER}

A newly lit fire comes to life... The boys huddle around the flames.

\section{NEIL}

I hereby reconvene the Welton Chapter of the Dead Poets Society. These meetings will be conducted by myself and by the rest of the new initiates now present. Todd Anderson, because he prefers not to read, will keep minutes of the meetings. (Todd is unhappy with this role but he tries not to show it.)

\section{NEIL}

I will now read the traditional opening message from society member Henry David Thoreau. (Neil opens Keating's copy of Thoreau's Walden, and reads.)

NEIL

"I went to the woods because I wanted to live deliberately." (skips thru the text) "I wanted to live deep and suck out all the marrow of life!"

\section{CHARLIE}

All right. I'll second that.

NEIL

"To put the rout all that was not life. (skips thru the text) And not, when I came to die, discover that I had not lived."

(Pledge Overstreet.)

(Script, 2007, pp. 37-38)

Again, facilitating third space to elicit students' meaning-making and subconsciously determines "students' language needs based on what they know and what they have experienced," (Pahl \& Rowsell, 2005, p. 105). Neil and friends finally find the cave to express not only imitating Mr. Keating's experiences but also expressing their exact desires, and their true preferences, particularly interconnected with their delightful passions in reading and learning poetry, and so forth. It asserts the theory of Knowledge dimension, particularly in Metacognitive Knowledge by Krathwohl (2002). This dimension highly emphasizes the awareness of one's own cognition and particular cognitive processes, particularly to include their own contextual and conditional knowledge and knowledge of self. Furthermore, the cave as the third place in this play exactly become a place where the students' are aware of their creativity and identity primarily based on their own experienced and their language or learning need. This situation is displayed in the Neil and friends' second meeting at the cave, as the excerpt script below. 


\section{EXT. CAVE - AFTERNOON}

The boys enter the cave.

INT. THE CAVE - AFTERNOON

It is a clear, crisp fall afternoon. Charlie, Knox, Todd, Necks, Neil, Cameron, and Pitts sit around. Neil recites from Thoreau.

NEIL

"I went to the woods because I wished to live deliberately. I wanted to live deep and suck out all the marrow of life."

KNOX

(moans) God, I want to suck all the marrow out of Chris. I'm so in love, I feel like I'm going to die!

NEIL

You know what the dead poets would say: "Gather ye rosebuds while ye may..."

KNOX

But she's in love with the moron son of my father's best friend. What would the dead poets say about that?

Knox walks away from the group. Despair is washing over him.

CHARLIE

I feel like I've never been alive. For years I've been risking nothing. I have no idea what

I am or what I want to do! Neil, you know you want to act. Knox wants Chris.

KNOX

Needs Chris! Must have Chris!

CHARLIE

Meeks, you're the brain here. What do the dead poets say about somebody like me?

MEEKS

The romantics were passionate experimenters, Charles. They dabbled in many things before settling, if ever.

\section{CAMERON}

There aren't too many places to be an experimenter at Welton, Meeks. Charlie paces a moment, then gets an idea. He addresses the group.

\section{CHARLIE}

I hereby declare this the Charles Dalton Cave for Passionate Experimentation. In the future, anyone wishing entry must have permission from me.

\section{PITTS}

Wait a minute, Charlie. This should belong to the club.

\section{CHARLIE}

It should, but I found it and now I claim it. Carpe Cavem, guys. Seize the cave. Charlie grins. The boys look at each other and shake their heads. Neil heads out.

NEIL

I gotta get to the tryouts. Wish me luck.

\section{MEEKS}


Good luck.

(Neil exits. Charlie finds a rock and begins carving his name on a wall of the cave.

Pitts shakes his head.)

(Script, 2007, pp. 45-47)

At the third meeting below, Neil and friends are getting more creative and fruitfully exploring their potentials talented skills which never been accommodated by the teachers, moreover the school's principles. Simply, because Welton Academy is a strict school which has a motto "Tradition, Honor, Discipline, and Excellence." Teachers, moreover students should obey all school's traditions and school's rules, and harmful to pronounce their ideas against the school's policies. The only way to actualize their identities, their personalities, and their capabilities is beyond the school, it is in the cave. Over there, once, Charlie plays his saxophone beautifully, and he makes-meaning on his action as "Poetrusic"; a combination of reading the poem and playing music. The vignette of Charlie is the best practice example to comprehend the essential role of third space in education subject, as the intersection of school lesson (poetry) and of home cultural capital (music skill). In Metacognitive Knowledge, Charlie is regarded as the one who has already aware of his own cognition and knowledge.

\section{EXT. DEAD POETS CAVE - AFTERNOON}

Boys enter the cave.

INT. DEAD POETS CAVE - AFTERNOON

Neil hurries in carrying a small, broken statue. The other pledges of the Dead Poets Society are assembled around Charlie who sits silently cross-legged before them. His eyes are closed and, in one hand, he holds an old saxophone.

NEIL

Look at this.

PITTS

What is it?

NEIL

The god of the cave. The statue has a stake sticking cut of its head with a candle stuck in it. Neil plants the statue in ground and lights the candle. It illuminates a red and blue drummer boy, face pitted from exposure, yet noble in its visage. Charlie, who hasn't moved, clears his throat. All turn to him and settle in.

\section{CHARLIE}

Gentlemen, "Poetrusic" by Charles Dalton. He blows scattered notes on the saxophone. Random, blaring, they sound like bad John Cage. Suddenly Charlie stops.

CHARLIE

(trance-like, run-on delivery)

CHARLIE 
Laughing, crying, tumbling, mumbling, gotta do more. Gotta is more. He plays more notes on the sax, then:

\section{CHARLIE}

(more rapid than before) Chaos screaming, chaos dreaming, crying, flying, gotta be more!! Gotta is more!!

Charlie plays a simple but absolutely gorgeous melody. The skeptical looks on the faces of the boys disappear. As Charlie gets lost in the music, so do the others. The melody ends with a long, beautiful, haunting note.

NEIL

Charlie, That was great! Where did you learn to play like that?

CHARLIE

My parents made me take clarinet but I hated it. (putting on a mock British accent) The sax is more sonorous.

(Script, 2007, pp. 55-56)

\section{CONCLUSION}

In the paradigm of New Literacy Studies, literacy has worked as both set of skills and a social practice. In this paper, Mr. Keating worth fully initiates and bears his students into new space, a cave as the third space, deals with high-level thinking or cognitive knowledge, as well as enables his students to create a social transformation for themselves and communities. These transformations are clearly delineated very well by Neil and friends at the first, second and third meetings in a cave. Practically, their inner potential abilities, their cultural artifacts at home and their school lesson are melted and mixed at third space and finally exposing their awareness of gathering new knowledge and of recognizing their own cognition.

In conclusion, this literary work intimately narrates Anderson and Krathwohl's Knowledge dimension in Metacognitive Knowledge category, as well as the Cognitive Process dimension in Remember category (2001). Simply, because literacy has been working as the social practice which subconsciously forms and shapes positive transformation toward students' identities and characteristics. Literacy affects and is affected mostly by the awareness of one's own cognition and particular cognitive processes. Thus, it is indispensable for teachers to do a similar thing and to stimulate their students' creativities and innovations beyond their homes and schools.

\section{REFERENCES}

Anderson, L. W., \& Krathwohl, D. R. (2001). A Taxonomy for Learning, Teaching, and Assessing: A Revision of Bloom's Taxonomy of Educational Objectives. . New York: Addison Wesley Longman. 
Barton, D., Hamilton, M., \& Ivanič, R. (2000). Introduction: exploring situated literacies. In D. Barton, M. Hamilton, \& R. Ivanič (Eds.), Situated Literacies; Reading and Writing in Context. London: Routledge.

Krathwohl, D. R. (2002). A Revision of Bloom's Taxonomy: An Overview. Theory into Practice, 41(4).

Luke, A. (2005). Foreword. In K. Pahl \& J. Rowsell (Eds.), Literacy and Education. London: Paul Chapman Publishing.

Moje, E. B., Ciechanowski, K. M., Kramer, K., Ellis, L., Carrillo, R., \& Collazo, T. (2004). Working toward third space in content area literacy: an examination of everyday funds of knowledge and discourse. Reading Research Quarterly, $39(1), 38-70$.

Pahl, K., \& Rowsell, J. (2005). Literacy and Education London: Paul Chapman Publishing.

Rednaningdyah, P. (2015). The Great Good Place: Antara Rawon Paidi, Perpustakaan Koper BMI-HK, dan Starbucks. Retrieved from My Stream of Consciousness website: http://tiwi-lioness.blogspot.co.id/

Script, T. D. (2007). Dead Poets Society Retrieved from http://www.dailyscript.com/scripts/

Wilson, A. (2000). There is no escape from third-space theory: borderland discourse and the 'in-between' literacies of prisons. In D. Barton, M. Hamilton, \& R. Ivanič (Eds.), Situated Literacies; Reading and Writing in Context (pp. 51-66). London and New York: Routledge. 